\title{
Innovative, Non-stirred Bioreactors in Scales from Milliliters up to 1000 Liters for Suspension Cultures of Cells using Disposable Bags and Containers - A Swiss Contribution
}

\author{
Sören Werner ${ }^{b}$, Regine Eibl ${ }^{b}$, Christine Lettenbauer ${ }^{c}$, Marcel Röllc, Dieter Eibl ${ }^{b}$, Maria De Jesus ${ }^{e}$, \\ Xiaowei Zhang ${ }^{\text {af, }}$, Matthieu Stettlere, Stephanie Tissot ${ }^{a}$, Cedric Bürkie, Gilles Broccarda ${ }^{a}$, Markus \\ Kühner ${ }^{\mathrm{d}}$, Rolf Tannere ${ }^{\mathrm{e}}$ Lucia Baldi ${ }^{\mathrm{a}}$, David Hacker ${ }^{\mathrm{ae}}$, and Florian M. Wurmªe
}

\begin{abstract}
Innovative mixing principles in bioreactors, for example using the rocking of a platform to induce a backwards and forwards 'wave', or using orbital shaking to generate a 'wave' that runs round in a cylindrical container, have proved to be successful for the suspension cultures of cells, especially when combined with disposable materials. This article presents an overview of the engineering characteristics when these new principles are applied in bioreactors, and case studies covering scales of operation from milliliters to 1000 liters.
\end{abstract}

Keywords: Disposable bioreactors · Engineering characteristics · High density $\mathrm{CHO}$ cultures · Orbitally shaken - Wave-mixed

\section{Introduction}

The use of single-use cultivation systems, which consist of rigid or flexible plastics (e.g. polyethylene $(\mathrm{PE})$, polypropylene (PP), polytetrafluoroethylene (PTFE) or ethylene-vinyl acetate (EVA)), can be dated back to the early 1960s. In 1963 Falch and Heden from the Karolinska Institute reported advantageous cultivation results for bacteria and fungi in orbitally shaken

\footnotetext{
${ }^{7}$ Correspondence: Prof. F. M. Wurmae

Tel.: +41216936145

Fax: +41216936140

E-mail: florian.wurm@epfl.ch

É́cole Polytechnique Fédérale de Lausanne

Faculty of Life Sciences, Laboratory of Cellular Biotechnology

$\mathrm{CH}-1015$ Lausanne

'Zürcher Hochschule für Angewandte Wissenschaften Institut für Biotechnologie

$\mathrm{CH}-8820$ Wädenswil

Sartorius Stedim Switzerland AG

$\mathrm{CH}-8317$ Tagelswangen

Adolf Kühner AG

$\mathrm{CH}-4127$ Birsfelden

ExcellGene

$\mathrm{CH}-1870$ Monthey

Nanchang University

Institute of Translational Medicine

330031, Nanchang, Jiangxi, PR China

gMerck-Serono SA

$\mathrm{CH}-1804$ Corsier-sur-Vevey

TPP Techno Plastics Products

$\mathrm{CH}-8219$ Trasadingen
}

tetrahedron bags made out of plastic. ${ }^{[1]} 14$ years later, Kybal and Vlcek from SPOFA in the former Czechoslovakia cultivated filamentous fungi within a sterile, pillowshaped plastic bag with a horizontal oscillating movement generated in a cultivation chamber. ${ }^{[2]}$ The wave was induced by the movement and thus, mixing with constantly renewal of the fluid surface for surface aeration and mechanical foam suppression was achieved. A patent in $1983^{[3]}$ and a publication two years later ${ }^{[4]}$ described for the first time the suitability of wave-mixed bags for plant and animal cell cultivations.

This led to the first commercially available wave-mixed bag bioreactors on laboratory scale, as well as for scale-up in GMP production, developed as a result of a cooperation between Wave USA and Wave Biotech, Switzerland in the late 1990s. ${ }^{[5]}$ The Swiss BioWave was the precursor to the Sartorius Stedim's BIOSTAT ${ }^{\circledR}$ Cultibag RM (max. 600 L volume). The American Wave Bioreactor, distributed by GE Healthcare Life Sciences, offers a maximal volume of $1000 \mathrm{~L}$. Both this system and the BIOSTAT $^{\circledR}$ Cultibag RM - separated not only by their different culture volumes but also through their use of different sensors and controlling systems - have found their place in process development and biopharmaceutical production despite initial skepticism based on the novel mixing principle.

The third largest group of bioreactor types after stirred and wave-mixed systems are orbitally shaken bioreactors (multiwell plates, tubes, Erlenmeyer flasks, Nalgene vessels, cylindrical bags). ${ }^{[5]}$ Their increasing popularity for mammalian cell culture is based on the observation that orbitally shaken cylindrical vessel expose cells to lower shear stress than those in stirred tanks, coupled with efficient mixing and gas transfer. ${ }^{[6-8]}$

The development of the TubeSpin technology by teams of scientists at the Laboratory of Cellular Biotechnology at the EPFL and at the company ExcellGene SA in Monthey goes back to the beginning of this century. ${ }^{[8-10]}$ The most recent result of this work is a disposable 200 Liter Orbitally Shaken Bioreactor System (OrbShake ${ }^{\mathrm{TM}}$ bioreactor) - commercially available since 2009, developed in cooperation between Adolf Kühner AG, the EPFL-LBTC laboratory ExcellGene SA and Sartorius Stedim Biotech SA for the bag technology. ${ }^{[11,12]}$

\section{BioWave ${ }^{\circledR}$ and BIOSTAT $^{\circledR}$ CultiBag RM}

\subsection{Engineering Characteristics}

Mass and energy transfer in the BioWave $^{\circledR}$ and BIOSTAT $^{\circledR}$ Cultibag RM are dependent on the development and propagation of the wave within the multilayer bag und can be varied by the rocking rate, the rocking angle, the filling volume ( $\mathrm{min}$. $10 \%$ and max. $50 \%$ of nominal volume), the geometry of the bag, the aeration rate and the viscosity of the culture broth. Ex- 
periments evaluating oxygen mass transfer (dynamic gassing out method) in water and cell culture medium at typical process parameters for mammalian cells $\left(6-10^{\circ}\right.$ rocking angle, 25-30 rpm, $0.25 \mathrm{vvm}, 40-50 \%$ filling level) showed $\mathrm{k}_{\mathrm{L}}$ a values between 6 and $10 h^{-1} .{ }^{[13]}$ The oxygen mass transfer can be improved more efficiently by increasing the rocking rate and the rocking angle rather than increasing the aeration rate. A decrease in the oxygen mass transfer rate is mostly dependent on an increase in viscosity, due to the addition of cell protection agents and/or antifoam agents or due to secreted polysaccharides, which affects the propagation of the wave and the fluid flow and thus, mixing efficiency and mass transfer rates decrease. ${ }^{[14]}$

First investigations regarding the fluid flow (modified Re number between 1500 and 4000 with critical modified Re number between 200 and 1000, which means fully established turbulent flow), mixing time (between $20 \mathrm{~s}$ and $50 \mathrm{~s}$ ), residence time (ideally stirred tank behavior) and volumetric power input (between $70 \mathrm{~W} \mathrm{~m}^{-3}$ and $180 \mathrm{~W} \mathrm{~m}^{-3}$ ) showed similar results to stirred cell culture bioreactors made out of glass or stainless steel under comparable process parameters. ${ }^{[15]}$

The strong influence of rocking angle and rocking rate on power input and hence the shear stress acting on the cells was demonstrated recently for CultiBag 2 $\mathrm{L}$ and $200 \mathrm{~L}$ at maximum fill levels (Fig. 1) using Computational Fluid Dynamics (CFD) simulations. ${ }^{[16]}$ One significant advantage of CFD is that both the minima and maxima of the fluid flow parameters of interest can be determined at any time and at any location within the reactor chamber. Average values of the fluid flow parameters of interest representing the whole fluid domain can also be generated using CFD. A three-dimensional, two-phase model was evaluated using the commercial software Ansys Fluent. Interestingly, the volumetric power input in a CultiBag $2 \mathrm{~L}$ at a rocking angle of $6^{\circ}$ and a rocking rate of $30 \mathrm{rpm}$ is lower $\left(81 \mathrm{~W} \mathrm{~m}^{-3}\right)$ than with a $10^{\circ}$ and 20 $\mathrm{rpm}\left(97 \mathrm{~W} \mathrm{~m}^{-3}\right)$ rocking angle and rocking rate respectively. ${ }^{[16]}$

Finally, the discovery that a more homogeneous energy dissipation (and hence a more homogeneous shear stress pattern) occurs within the BIOSTAT $^{\circledR}$ CultiBag RM compared to stirred bioreactors with a Rushton turbine or paddle impeller (Fig. 2) could explain the higher cell counts and higher product titers which have been shown in many comparative studies. ${ }^{[13]}$ The availability of such engineering data for the BioWave $^{\circledR}$ and BIOSTAT ${ }^{\circledR}$ CultiBag RM allows comparison with other conventional and single-use bioreactors and simplifies the optimization of the process depending on the organisms to be cultivated, and the scale-up.

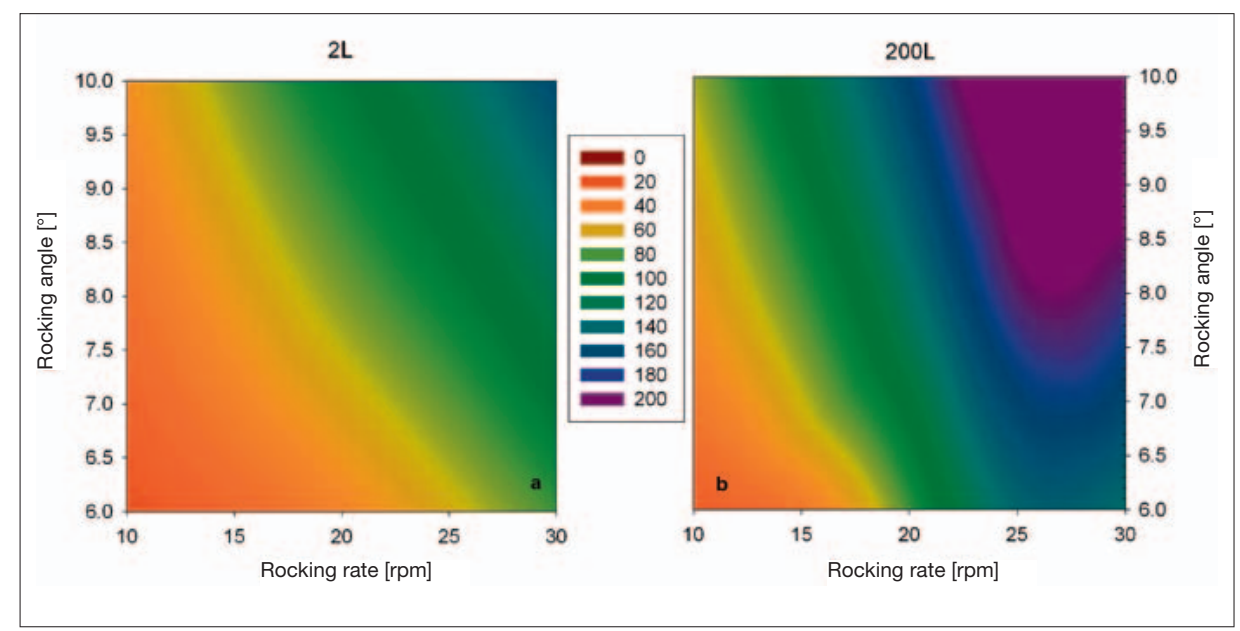

Fig. 1. Contour plot of specific power input in the BIOSTAT ${ }^{\circledR}$ Cultibag RM $2 \mathrm{~L}$ (a) and $200 \mathrm{~L}$ (b) at different rocking rates and rocking angles with maximum filling level ( $1 \mathrm{~L}$ and $100 \mathrm{~L})$. Adapted according to ref. [16].

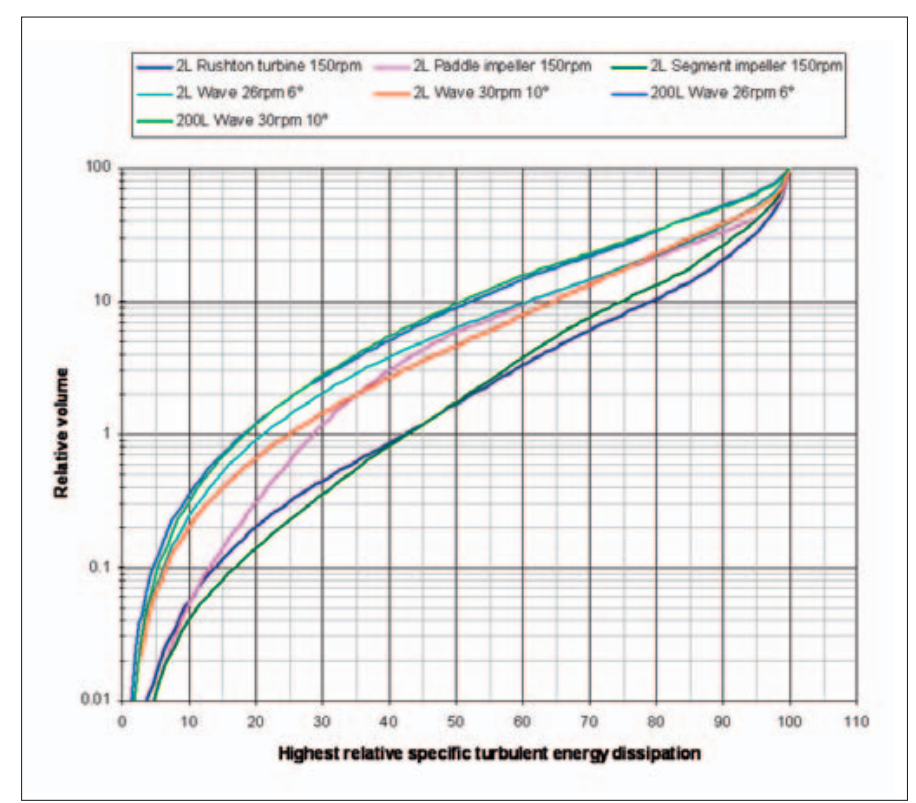

Fig. 2. Spatial distribution of specific turbulent energy dissipation rate in different bioreactor systems with maximum filling levels. Adapted according to ref. [16].

\subsection{Typical Applications with Suspension Cells}

Publications describing applications in wave-mixed single-use bioreactors (the BioWave $^{\circledR}$ and its successor the BIOSTAT ${ }^{\circledR}$ CultiBag RM) are wide-ranging. ${ }^{[13]}$ Batch, fed-batch and continuous (perfusion) processes have been successfully implemented. There are five main applications for suspension cells: i) seed inoculum and seed train production, ii) the production of glycoproteins (including antibodies) for therapy and diagnostics with mammalian cells, iii) the production of tool proteins and virus-like particles (VLP) with insect cells and the baculovirus expression vector system (BEVS), iv) the mass propagation of plant suspension cells for the production of bioactive substances for the cosmetic industry and v) the production of secondary metabolites and glycoproteins with plant cell suspensions for the pharmaceutical industry. Table 1 shows a summary of successful studies with suspension cells using the wave-mixed BioWave $^{\circledR} /$ BIOSTAT $^{\circledR}$ CultiBag RM carried out at the Zurich University of Applied Sciences between 1998 and 2010.

Of particular interest are processes with fast-growing plant cell suspensions of Malus domestica, Vitis vinifera and the tobacco cell line BY-2 with doubling times of 18-48 $\mathrm{h}$ using the standard CultiBag with screw cap. ${ }^{[14,17-19]}$ Despite an increase in the viscosity by a factor between 70 and 400 and biomass production of $35-67 \mathrm{~g}$ fresh weight per day and liter culture volume, wave-mixed systems distinguish themselves against stirred laboratory bioreactors due to the lack of flotation and no need for antifoam agents.

The performance of the BioWave ${ }^{\circledR}$ and BIOSTAT $^{\circledR}$ CultiBag RM in comparison to stirred systems with insect cell-based 
Table 1. Selected, successfully implemented applications with suspension cells in the BioWave ${ }^{\circledR /}$ BIOSTAT ${ }^{\circledR}$ CultiBag RM

\begin{tabular}{|c|c|c|c|c|}
\hline Application field & Product & Cells & CVa [L] & Reactor $\mathrm{m}$ \\
\hline $\begin{array}{l}\text { i) Seed inoculum } \\
\text { and seed train } \\
\text { production }\end{array}$ & $\begin{array}{l}\text { Expanded animal } \\
\text { cells }\end{array}$ & $\begin{array}{l}\mathrm{CHO}^{b} \text { XM 111- } \\
10, \text { CHOeasy C, } \\
\text { Freestyle CHO, } \\
\mathrm{Sf}^{c}-9, \mathrm{~S} f-21, \\
\mathrm{Hi}^{-} 5^{d}\end{array}$ & $1-100$ & $\begin{array}{l}\text { Fed batch, } \\
\text { continuous } \\
\text { perfusion }\end{array}$ \\
\hline \multirow[t]{2}{*}{$\begin{array}{l}\text { ii) Mammalian cell- } \\
\text { derived glycoprotein } \\
\text { production }\end{array}$} & $\begin{array}{l}\text { SEAP, antibody for } \\
\text { Alzheimer's disease }\end{array}$ & $\begin{array}{l}\mathrm{CHO} \text { XM 111- } \\
10^{\mathrm{e}}, \text { Freestyle } \\
\mathrm{CHO}^{f}\end{array}$ & $1-10$ & $\begin{array}{l}\text { Fed batch, } \\
\text { continuous } \\
\text { perfusion }\end{array}$ \\
\hline & Resistin & HEK-293 EBNA ${ }^{\text {eg }}$ & $1-100$ & $\begin{array}{l}\text { Fed batch, } \\
\text { continuous } \\
\text { perfusion }\end{array}$ \\
\hline \multirow{2}{*}{$\begin{array}{l}\text { iii) Production of tool } \\
\text { proteins and VLP } \\
\text { vaccines with insect } \\
\text { cells and BEVS }\end{array}$} & B-Raf kinase & $\mathrm{S} f-21$ & 1 & Fed batch \\
\hline & $\begin{array}{l}\text { hERG' }{ }^{\mathrm{h}} \text { proteins } \\
\text { Influenza VLPs }\end{array}$ & Sf-9 & 1 & Fed batch \\
\hline $\begin{array}{l}\text { iv) Plant cell } \\
\text { biomass for usage } \\
\text { in cosmetics }\end{array}$ & $\begin{array}{l}\text { Skin stem cell } \\
\text { regenerating } \\
\text { substances } \\
\text { from expanded } \\
\text { suspension cells } \\
\text { (PhytoCELLTec }^{\text {TMi }} \text {, } \\
\text { Super Booster) }\end{array}$ & $\begin{array}{l}\text { Malus domestica } \\
\text { (Uttwiler } \\
\text { Spätlauber) } \\
\text { suspension cells }\end{array}$ & $1-10$ & Batch \\
\hline \multirow{3}{*}{$\begin{array}{l}\text { v) Plant cell- } \\
\text { based secondary } \\
\text { metabolite and } \\
\text { glycoprotein } \\
\text { production }\end{array}$} & Terpenoids & Vitis viniferak $^{k}$ & 1 & Batch \\
\hline & Taxanes & Taxus baccatalmn & 0.4 & Fed batch \\
\hline & M12 antibody & $\begin{array}{l}\text { Nicotiana } \\
\text { tabacum (BY-2) }\end{array}$ & 1 & Batch \\
\hline
\end{tabular}

${ }^{a}$ Culture volume, ${ }^{b}$ Chinese hamster ovary, ${ }^{c}$ Spodoptera frugiperda, ${ }^{d}$ Trichoplusia ni, etemperature shift, 'transient transfection, ${ }^{9}$ quasi-stable, "human ether-a gogo related gene, 'commercially available product of Mibelle Biochemistry AG, ${ }^{\mathrm{j}} \mathrm{commercially}$ available product of Marbert, ${ }^{\mathrm{k} U V B}$ irradiation in production phase, 'immobilized cells, melicitation by methyljasmonate, "nadditional precursor feeding with mevalonate and N-benzoylglycine, ${ }^{\circ}$ cultivar Bright Yellow-2

processes for protein and VLP production can be attributed to the homogeneous energy dissipation described in Section 2.1. Recent investigations have shown that cells directly inoculated from cryovials or cryobags with appropriate process parameters (rocking rate, rocking angle, aeration rate) and optimized feeding strategy exhibit identical growth rates and metabolite profiles as cells prepared in shake flasks as an intermediate inoculation step (publication in preparation). The omission of the intermediate step contributes to a shortened production time and hence additional savings in process cost are possible.

Investigations regarding adherent mammalian cells growing on microcarriers (e.g. embryogenic feline lung fibroblasts, E-FL) for the production of viruses, plant tissue cultures (e.g. bioactive hairy root and embryogenic cultures of plant origin), production of bioactive substances with microorganisms (Escherichia coli, Erynia neoaphidis) and in vitro production of nematodes are not listed in Table 1 , however, details can be found in the literature. ${ }^{[13]}$

\section{Orbital Shaking Technology in Cylindrical Vessels}

3.1 TubeSpin ${ }^{\circledast}$ Bioreactor Technology for Small-scale Cultivation of Suspension Cultivated Mammalian Cells

The TubeSpin ${ }^{\circledR}$ bioreactor technology was initially developed by scientists at the EPFL in an attempt to screen hundreds of cell culture process parameters under

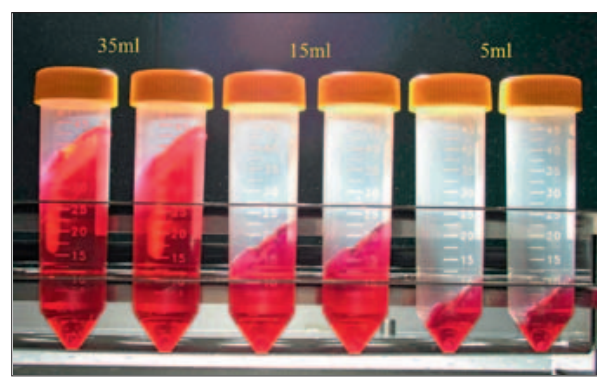

Fig. 3. TubeSpin ${ }^{\circledR}$ Bioreactor 50 : Vessels with different filling volumes from $5 \mathrm{~mL}$ to $35 \mathrm{~mL}$ under orbital shaking conditions in a Kühner Incubator/Shaker (ISF1-X) at 180 rpm.

'bioreactor-equivalent' conditions. ${ }^{[9]}$ Surprisingly, simple $50 \mathrm{~mL}$ centrifuge tubes, opened by turning the cap by one half turn and thus allowing diffusive entry of gas and shaken on a platform with 130-250 rpm, allowed the high density culture of CHO cells with productivity performance equivalent to fully controlled stirred tanks. For the first time a non-instrumented (no $\mathrm{pH}$, no $\mathrm{O}$, control) bioreactor system allowed high density cultures of industrial cell lines. The range of cell culture volumes applicable within these tubes (see Fig. 3) was optimized with respect to the shaking speeds, using humidified, $\mathrm{CO}_{2}$-controlled incubator shakers from Kühner AG. Eventually, a ventilated cap was designed by the Laboratory of Cellular Biotechnology (LBTC) group and the company TPP (Trasadingen) produced and began marketing the modified vessels under the name TubeSpin ${ }^{\circledR}$ bioreactor 50 (short 'TubeSpins'). TubeSpins (also available as CultiFlask 50 disposable bioreactor from Sartorius Stedim) have now become a widely used tool in the industry and are applied in medium and process development for mammalian cell cultures with suspension adapted cells. Fig. 4 shows the regular subcultivation of $\mathrm{CHO}$ cells in a seed train culture over many passages, here executed with a filling volume

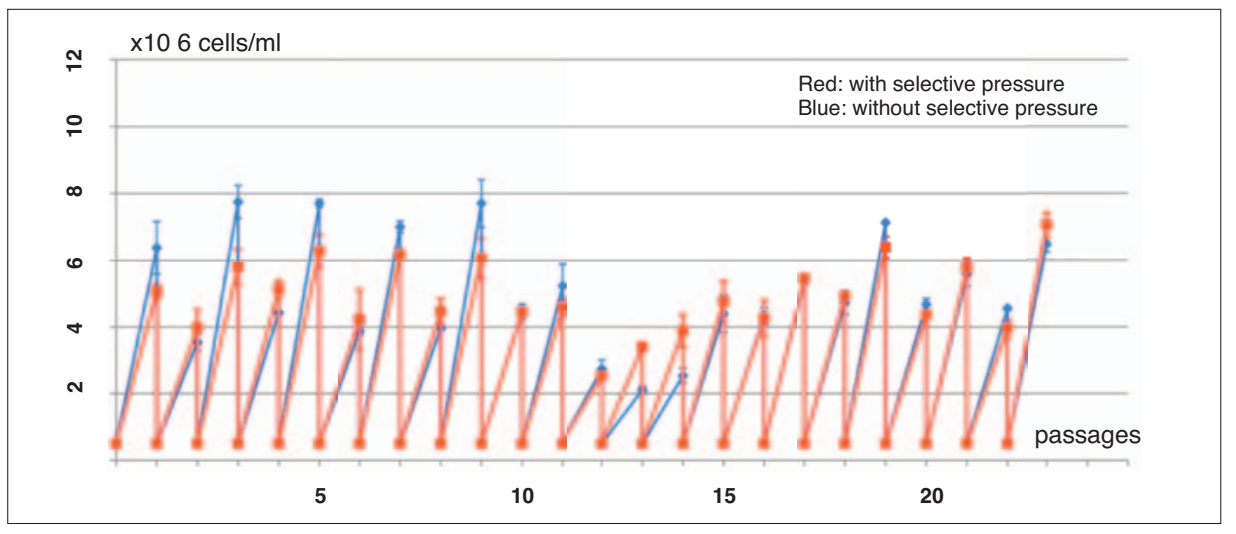

Fig. 4. Seed train cultures of $\mathrm{CHO}$ cells over extended period, executed in TubeSpin ${ }^{\circledR}$ bioreactor 50 vessels, here a stability study with and without puromycin. Cultures were executed in triplicates for each passage (data kindly provided by ExcellGene SA). 
of $10 \mathrm{~mL}$. Recently, insect cell cultures have been successfully executed in TubeSpins, with better performance than seen in any publication available today (publication in preparation). The 'large-scale bioreactor-equivalence' of TubeSpins has been reinforced by routine use of these reactors for the optimization of $\mathrm{CHO}$ and HEK-293 based manufacturing processes up to and exceeding $\mathrm{g} / \mathrm{L}$ expression levels. At LBTC and at ExcellGene, the availability of Kühner Shaker incubators with especially adapted holders for TubeSpins allows the simultaneous execution of up to 2000 bioreactor runs. A number of papers have been published in which standard and 'high-throughput' use of TubeSpins have provided important insights into gene transfer mechanisms during transfections and in transient expression with both $\mathrm{CHO}$ and HEK-293 cells. ${ }^{[20-22]}$

In studies on mixing time and gas transfer, done under conditions that allow culture with suspension culture adapted $\mathrm{CHO}$ cells, TubeSpin ${ }^{\circledR}$ bioreactors provided excellent results: With a filling volume of $5-10 \mathrm{~mL}$ and shaking speeds of $200 \mathrm{rpm}$, $\mathrm{k}_{\mathrm{t}}$ a values exceeding $80 \mathrm{~h}^{-1}$ were obtained. The high $\mathrm{k}_{\mathrm{L}} \mathrm{a}$ is the reason why diffusive oxygen supply through the ventilation holes of the cap (with an inserted sterile membrane) is sufficient to allow cells to grow to the maximal cell density supported by the provided medium. Since aeration in TubeSpins is bubble-free and the liquid movement in the vessel appears to be mostly laminar, the cells in the liquid are exposed to very low shear stress. Sensitive cells can be cultured in these vessels without the addition of shear protective agents, whereas the same cells cultivated in stirred cell culture bioreactors require the addition of Pluronic F68 (M. De Jesus, personal communication). CFD modeling studies have verified the very low shear stress in TubeSpin ${ }^{\circledR}$ bioreactors, and orbitally shaken cylindrical vessels for larger scale operation (paper in preparation).

\subsection{Disposable Orbitally Shaken Bioreactor Systems (OrbShake ${ }^{\mathrm{TM}}$ Bioreactors) for Large-scale Operations}

The scientific and technical development of a $200 \mathrm{~L}$ working volume OrbShake $^{\mathrm{TM}}$ bioreactor (SB 200-X, Kühner AG, Birsfelden) (see Fig. 5), equipped with a disposable bag from Sartorius-Stedim, was initiated and guided by the LBTC at the Swiss Federal Institute of Technology Lausanne, after intensive studies with selfassembled containers of various shapes and sizes, ranging in working volume from the $0.5 \mathrm{~L}$ to the $100 \mathrm{~L}$ scale, and since 2005 also at the $1000 \mathrm{~L}$ scale. $[6,8,10,11,23,24]$

In all these studies LBTC found very high oxygen transfer rates, low shear stress

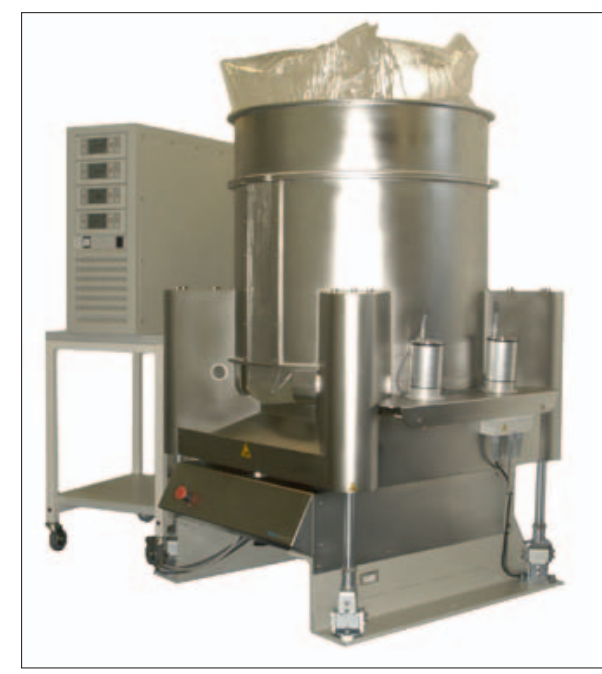

Fig. 5. OrbShake ${ }^{\mathrm{TM}}$ bioreactor (SB-200-X, Kühner AG, Birsfelden).

and highly efficient mixing. These findings provided confidence that a commercial, orbitally shaken bioreactor of a larger than $100 \mathrm{~L}$ scale working volume could be an alternative to standard stirred cell culture bioreactors for the upstream processing of suspension culture adapted mammalian cells. In a paper by Tissot et al., now accepted for publication in Biochemical Engineering Journal, ${ }^{[8]}$ the LBTC group established a scale-up factor that appears to be applicable over the entire range of reactor volumes and cylindrical vessels available today for orbital shaking $(0.1 \mathrm{~L}$ to $1000 \mathrm{~L}$ ). The so far mostly empirically obtained data on superior performance of orbital shaking for mammalian cell culture is being supported strongly by engineering studies which involve fluid dynamics modeling, fast camera-based evaluations of surface deformations at different shaking speeds and at different displacement radii, mixing time studies, gas transfer studies, power input studies etc. ( further publications in preparation).

Key to the efficiency of orbital shaking are the fast mixing times seen in all reactors, even under moderate shaking speeds, and in all scales of operation measured. For example, at the $1000 \mathrm{~L}$ scale complete mixing could be observed within less than 1 min using suitable conditions for mammalian cells.

In addition, and surely also as a consequence of efficient mixing, OrbShake ${ }^{\mathrm{TM}}$ bioreactors transfer gases in and out of the liquid environment faster than seen in wave-mixed and stirred bioreactors with mammalian cell culture applications. The high gas transfer rates contribute to the (biological) observation of high density cell cultures $\left(>1 \cdot 10^{7}\right.$ cells $\left.\mathrm{mL}^{-1}\right)$ achievable at a $200 \mathrm{~L}$ working volume with the 200 L OrbShake ${ }^{\mathrm{TM}}$ bioreactor (SB200-X) from Kühner AG without the use of pure oxygen. In contrast, even in a standard stirred Applikon bioreactor (1.5 L working volume) pure oxygen has to be supplied when cell densities rise to higher levels than $2 \cdot 10^{6}$ cells $\mathrm{mL}^{-1}$ (data ExcellGene). A working hypothesis for the exceptionally high efficiency of gas transfer is based on the following:

With the exception of TubeSpins, all larger cylindrical vessels used for orbital shaking so far tend to have a larger inner diameter than is typically seen for stirred cell culture bioreactor. The ratio of height over diameter is generally in the range of $1 / 1$ to $1 / 1.5$. This difference from stirred tanks is even more pronounced when considering the height of the liquid in the tank versus its diameter: In the larger scale reactors studied (100 L, 200 L, 1000 L working volumes), the ratio of the height of the liquid in the vessel to the reactor diameter of the cylinder is typically between $0.5 / 1$ to $1 / 1$ (variable, depending on filling volume). Thus any orbital movement of the liquid in the tank will also accelerate and eventually move the gas volume (head space) above the liquid, assumed to achieve eventually the same circular speed as the liquid in the lower part of the container. For the 1000 liter scale operation, at a mixing speed of 45 rpm the liquid will eventually move around the vessel at a speed of about $20 \mathrm{~km} \mathrm{~h}^{-1}$. In a TubeSpin ${ }^{\circledR}$ bioreactor 50 , at $250 \mathrm{rpm}$, the liquid moves at a speed of about $14 \mathrm{~km}$ $\mathrm{h}^{-1}$. At these speeds therefore any gaseous environment in the 'head space' is assumed to be accelerated and eventually mixed with the same or similar efficiency as the liquid. If then, in the head space of the reactor, oxygen consumption by cells in the liquid will reduce the oxygen concentration of the air, the difference in partial pressure will be equilibrated reasonably efficiently, either via diffusion through the sterile membrane behind the ventilation cap (in TubeSpins and in self-assembled vessels up to $5 \mathrm{~L}$ working volume, G. Broccard, personal communication) or by the constant flow of air which is provided in excess of the consumption rate in orbitally shaken bioreactors at larger than 5 L working volume. This approach has been found entirely satisfactory for cell cultures in excess of $1 \cdot 10^{7}$ cells $\mathrm{mL}^{-1}$ with a working volume of $200 \mathrm{~L}$ (C. Bürki, personal communication).

Ongoing work with $500 \mathrm{~L}$ and 1000 L working volume scales at LBTC and ExcellGene (with a prototype $1000 \mathrm{~L}$ OrbShake $^{\mathrm{TM}}$ bioreactor, provided kindly by Kühner AG) is continuing to provide important insights into the engineering on even larger bioreactors. Eventually, a disposable bioreactor system for a working volume of up to $2500 \mathrm{~L}$ scale will be manufactured by Kühner AG, bringing together the expertise of ExcellGene in cell culture 
processing and Sartorius Stedim Biotech SA for disposable bag technology. It remains to be seen whether the high expectations for this largest (working volume) disposable reactor can be met. But more importantly, in view of a Swiss contribution, one can state already today that innovative research and development efforts in Switzerland initiated and guided by two leading academic engineering institutions has been successful in providing the foundations for entirely new bioreactor families with proven acceptance and further growth potential in the market place.

\section{Conclusion and Outlook}

Due to their inherent characteristics, wave-mixed and orbitally shaken singleuse bioreactors are suitable for many processes in the range of small- to middlescale cultivation volume with Newtonian fluid properties with organisms with low to middle oxygen requirements. While wave-mixed single-use bioreactors like the BIOSTAT ${ }^{\circledR}$ Cultibag RM and the Wave Bioreactor are already in use for process development and the cultivation of mammalian cells, orbitally shaken single-use bioreactors are the dominating systems for cell line screening and parameter scouting in milliliter scale.

Because of the more uniform energy input and the negligible foaming compared to stirred systems, as reported for both the wave-mixed and orbitally shaken single-use bioreactors, it can be assumed that the recently introduced Disposable Shaken Bioreactor in production scale will become an interesting alternative to stirred tank bioreactors systems.

Future fields of application, which currently form the focus of Swiss research teams, are the production of personalized antibodies with mammalian cells, insect cell-based production of antibodies, viruses and virus-like particles (VLP) for vaccine production, stem cell expansion and plant cell based production for bioactive substances for pharmaceutical and cosmetic industry. Furthermore, the use of microbial cultivations for the production of high value products is being considered.

\section{Acknowledgement}

The team from ZHAW would like to thank Lidija Lisica, Johanna Brändli, Irina Bauer, Nathalie Riesen and Christoph Ries for their considerable contribution in performing the experimental trials, as well as all the academic cooperation partners for their valuable sharing of knowledge and know-how. Furthermore, we would like to thank our industry partners and the CTI for their financial support working with the BioWave ${ }^{\circledR} /$ BIOSTAT $^{\circledR}$ Cultibag RM.

The team from LBTC at the EPFL thanks the CTI and the Swiss Science Foundation for the continuing support in the field of orbital shaking technology. Generous support for materials and media is also acknowledged to the companies ExcellGene, Kühner AG, Sartorius-Stedim SA and TPP.

Received: September 6, 2010

[1] F. A. Falch, C. G. Heden, Biotechnol. Bioeng. $1963,5,211$.

[2] J. Kybal, V. Vlcek, Biotechnol. Bioeng. 1976, $18,1713$.

[3] V. Vlcek, J. Kybal, J. Chromik, 1983, Patent Publication number DE32 48543 A1.

[4] J. Kybal, B. Sikyta, Biotechnol. Lett. 1985, 7, 467.

[5] R. Eibl, S. Kaiser, R. Lombriser, D. Eibl, Appl. Microbiol. Biotechnol. 2010, 86, 41

[6] X. Zhang, C. A. Bürki, M. Stettler, D. De Sanctis, M. Perrone, M. Discacciati, N. Parolini, M. DeJesus, D. L. Hacker, A. Quarteroni, F. M. Wurm, Biochem. Eng. J. 2009, 45, 41.

[7] U. Maier, M. Losen, J. Büchs, Biochem. Eng. J. 2004, 17, 155.

[8] S. Tissot, M. Farhat, D. L. Hacker, T. Anderlei, M. Kühner, C. Comninellis, F. M. Wurm, 'Determination of a scale-up factor from mixing time studies in orbitally shaken bioreactors', Biochem. Eng. J. 2010, 52, 181.

[9] M. J. De Jesus, P. Girard, M. Bourgeois, G. Baumgartner, B. Kacko, H. Amstutz, F. M. Wurm, Biochem. Eng. J. 2004, 17, 217.

[10] N. Muller, P. Girard, D. Hacker, M. Jordan, F M. Wurm, Biotechnol. Bioeng. 2004, 89, 400 .

[11] X. Zhang, M. Stettler, D. De Sanctis, M. Perrone, N. Parolini, M. Discacciati, M. De Jesus, D. Hacker, A. Quarteroni, F. Wurm, in 'Disposable bioreactors', Ed. D. Eibl, R. Eibl, Series Adv. Biochem. Engin./Biotechnol, 115, Springer, Berlin Heidelberg, 2009, p. 33

[12] T. Anderlei, C. Cesana, C. Bürki, M. De Jesus, M. Kühner, F. Wurm, R. Lohser, http:// www.genengnews.com/gen-articles/shakenbioreactors-provide-culture-alternative/3092/, 2009, accessed 25 June 2010

[13] R. Eibl, S. Werner, D. Eibl, in 'Disposable bioreactors', Ed. D. Eibl, R. Eibl, Series Adv. Biochem. Engin./Biotechnol. 115: Springer, Berlin Heidelberg, 2009, p. 55.

[14] R. Eibl, S. Werner, D. Eibl, Eng. Life Sci. 2009 , 9, 156.

[15] R. Eibl, D. Eibl, in 'Plant tissue culture engineering', S. Dutta Gupta, Y. Ibaraki, Series Focus on biotechnology 6: Springer, Dordrecht, 2006, p. 203

[16] C. Löffelholz, S. C. Kaiser, S. Werner, D. Eibl, in 'Single-Use Technology in Biopharmaceutical Manufacture', Ed. R. Eibl, D. Eibl, Wiley, in press.

[17] A. Krüger, Diploma thesis, University of Applied Sciences Anhalt, Department of Applied Biological Sciences and Process Techniques, 2006, unpublished.

[18] S. Cuperus, R. Eibl, T. Hühn, R. Amado, BioForum Europe 2007, 6, 2.

[19] C. Schürch, P. Blum, F. Zülli, Phytochem. Rev. 2008, 7, 599.

[20] M. Bertschinger, G. Backliwal, A. Schertenleib, M. Jordan, D. L. Hacker and F. M. Wurm, $J$. Control Release 2006, 116, 96.

[21] G. Backliwal, M. Hildinger, S. Chenuet, M. De Jesus, F. M. Wurm, New Biotechnology 2008, $12,162$.

[22] S. Wulhfard, L. Baldi, D. L. Hacker, F. M. Wurm, J. Biotechnol. 2010, 148, 128.

[23] N. Muller, P. Girard, M. Jordan, F. M. Wurm, Biotechnol. Bioeng. 2005, 89, 400

[24] M. Stettler, X. Zhang, D. L. Hacker, M. De Jesus, F. M. Wurm, Biotechnol. Prog. 2007, 23 , 1340. 